\title{
WHAT SHOULD STUDENTS PAY FOR UNIVERSITY COURSE READINGS? AN EMPIRICAL, ECONOMIC, AND LEGAL ANALYSIS
}

\author{
JOHN WILLINSKY \\ STANFORD UNIVERSITY
}

\author{
CATHERINE BARON \\ STANFORD UNIVERSITY
}

\begin{abstract}
The digital transformation of knowledge dissemination and academic publishing have sparked copyright disputes in the educational sector related to the scope of fair dealing. This study contributes (a) an empirical basis for such discussions by analyzing 3,391 course syllabuses (2015-2020) from 34 Canadian universities, and (b) a potential resolution to the disputes to which this analysis is applied. Among the reading types, $26.6 \%$ of the syllabuses had readings from academic sources, while $8.3 \%$ of the syllabuses had media articles and trade book chapters (with some overlap). The syllabus data are used to calculate a per-page royalty charge, which is used to demonstrate a proposed three-step syllabus rule to avoid double-charging students for academic materials (amounting to $90.1 \%$ of readings by pages), while fairly compensating professional authors and their publishers ( $9.9 \%$ of readings by pages). The three-step syllabus rule provides a sound rationale for charging each student $\$ 1.40$ per year to cover royalty charges for readings assigned in Canadian university courses.
\end{abstract}

Keywords: higher education, scholarly publishing, copyright, syllabus readings, university libraries

\section{Résumé}

La transformation numérique de la diffusion des connaissances et de l'édition universitaire a déclenché des litiges en matière de droit d'auteur dans le secteur de l'éducation, liés à la portée de l'utilisation équitable. Cette étude propose a) une base empirique pour de telles discussions en analysant 3391 plans de cours (2015-2020) de 34 universités canadiennes, et b) une solution potentielle aux différends auxquels cette analyse est appliquée. Parmi les types de lectures, $26,6 \%$ des plans de cours comportaient des lectures provenant de sources universitaires, tandis que 8,3\% comportaient des articles de presse et des chapitres de livres généraux (avec un certain chevauchement). Les données tirées des plans de cours sont utilisées pour calculer une redevance par page, qui est utilisée pour démontrer une proposition de règle en trois étapes visant à éviter de faire payer les étudiants en double pour le matériel de cours (équivalant à $90,1 \%$ des lectures par page), tout en assurant la juste rémunération des auteurs professionnels et de leurs éditeurs ( $9,9 \%$ des lectures par page). La règle en trois étapes constitue un fondement solide pour facturer à chaque étudiant 1,40 \$ par année afin de couvrir les redevances pour les textes donnés à lire dans les cours universitaires canadiens.

Mots-clés : enseignement supérieur, édition savante, droits d'auteur, lectures obligatoires, bibliothèques universitaires

\section{Introduction}

When it comes to the readings assigned to students participating in Canadian university courses, two types prevail: the textbook, a pedagogical work dedicated to instructing students in a particular topic, and readings, made up of research articles, book chapters, and ex- cerpts drawn from scholarly and trade publications. The assignment of readings has been plagued by copyright disputes since the age of the photocopy, with little let-up in the move from surelock-bound photocopied coursepacks to cloud-based downloads. The infringement litigation that inspired this article began with Access Copyright's suit against York University in 2013 (and is 
still before the courts as we write), which claims that the use of assigned course readings constitutes copyright infringement, with the university defending itself by holding that assigned course readings qualify as fair dealing (discussed below). This article is also intended to address a knowledge gap that policy makers have identified in grappling with the scope of fair dealing in the digital context. In the 2019 Statutory Review of the Copyright Act Report, Canada's Standing Committee on Industry, Science, and Technology proposed to "resume its review of the implementation of educational fair dealing in the Canadian educational sector within three years, based on new and authoritative information as well as new legal developments" (Ruimy, 2019).

The data-gathering and analysis draw on a historical distinction between scholarly publishing, in which authors are paid by universities and research institutes, and trade publishing, in which authors earn their living by the sale of their writing (Willinsky, 2017). ${ }^{1}$ The study also builds on how research libraries have taken to purchasing institutional or site licences to the academic literature. This licence gives the university's entire community ready access to scholarly knowledge in a way that the purchase of a single copy of a journal or a book does not. This study assembles and analyzes data on the readings assigned on Canadian university syllabuses, before going on to demonstrate, using this data, how artificial intelligence might be applied through a proposed threestep syllabus rule to achieve a new legal strategy that deals fairly with all parties.

\section{Literature Review and Legal Context}

The move to digital scholarly readings in university courses, from its earliest days in the 1990s, was welcomed by faculty, whose teaching had been transformed by the ability to distribute photocopies of research studies and scholarly materials to their classes (Shepherd \& Bleasdale, 1993). Librarians and faculty noted that online copies reduced the loss and destruction of readings common to reserve systems (Parnell et al., 2003), with evidence gradually emerging that students appear to read more (or at least access more) readings when in digital form (Rojeski, 2012). Still, the digital move also introduced a financial conflict to the charging of students for the distribution of course readings. A2013 study, con- ducted by one of the authors of this article, for example, determined that $45.1 \%$ of the readings purchased by students in 110 Stanford University and Queen's University course packs had been freely available to them from their respective libraries and through open access (Evans \& Willinsky, 2013). In 2017, a study of 12 University of Toronto courses further pointed to the "double-charging" of students because " 55 percent of the assigned readings were already licensed by the library and were fully available in electronic form" (Cancilla et al., 2017, p. 6). In other words, students are paying a royalty fee for course readings that the university library, using students' tuition fees, had already purchased a campus-wide licence for, with some libraries having done more over the last decade to ensure that students are able to access the library's licensed copy for their courses (Canuel \& Crichton, 2011; Tabacaru \& Hartnett, 2017).

On the legal front, course-reading collections, known as coursepacks or course readers, have attracted copyright infringement suits since the 1980s' proliferation of copy-shops that made this eclecticism of readings a practical reality for higher education courses. The early key decisions are found in the United States, with Basic Books v. Kinko's Graphics (1991) followed by Princeton Univ. Press v. Michigan Document Servs (1996), both of which established that photocopying course readings without sharing the profits with the publishers constituted infringement rather than the fair use exception recognized in the United States Copyright Act (Frey, 1998). The move to digital files only complicated the picture, turning the course reader into what Pflugfelder colourfully describes as "an object from the underworld, from the abyss beneath the post-historical university" (2012, p. 249). In 2008, Georgia State University was sued by multiple publishers over its use of electronic reserves in Cambridge University Press v. Becker, a case that has dominated the American side of this question on course readings through a dozen years of appeals and remands. The most recent ruling in 2020 very much favours a reading-by-reading determination of fair use based on the four factors that govern exemption, with the court finding that the majority of readings in this case qualified as fair use (Schow, 2020). ${ }^{2}$

In the Canadian context, Access Copyright, which represents 11,000 Canadian writers, visual artists, and publishers, sued York University in 2013 over its failure to pay the tariff approved by the Copyright Board of Canada to cover the millions of copied pages that were said 
to be assigned in York courses from 2011 to $2013 .{ }^{3}$ In 2017, the federal court ruled against York, holding that "the Interim Tariff is mandatory" and "the York Fair Dealing Guidelines are not fair" for, among other reasons, its "material negative impacts on the market" (Canadian Copyright Licensing Agency v. York University, 2017, paras 13, 356, 353)..$^{4}$ In 2020, the Federal Court of Appeal countered that "the tariff is not mandatory"; the Copyright Board of Canada tariff-setting process is only intended to protect the public from excessive pricing (York University v. Canadian Copyright Licensing Agency, 2020, para. 206). However, the appeals court also upheld the earlier decision that "York's Guidelines did not ensure that copying....was necessarily fair dealing" (para. 311). Chapdelaine (2021) has drawn from this case that the only path to deciding what is fair for students and authors is to pursue greater documentation and communication around coursepacks, which is one part of the position this study takes, beginning with the data analysis presented here.

Also in response to the York case, Wilkinson (2019) provides support for the approach taken in this article by holding that any infringement decisions need to consider that academic authors are employed by universities: "The question then arises whether it would be double- or triple-paying for material [used in courses] by purchasing an Access Copyright license, both through this subsidization [of academic authors] as well as through other licensing agreements" $(2019$, p. 210). At this point, the Supreme Court of Canada is hearing York University $v$. Access Copyright, with factum submitted to the court citing data from a preprint of this paper (Katz, 2021).

\section{Method}

\section{Sample}

Using web-scraping strategies to collect course syllabuses at Canadian universities, we assembled 5,898 documents from 34 of Canada's 96 universities located in nine of Canada's 10 provinces, while missing Prince Edward Island (Table 1). Of these, 3,916 proved to be unique syllabuses for the period 2015-2020. We eliminated 525 syllabuses that did not identify the readings but may have referred to a coursepack or a website. This left 3,391 syllabuses, of which 2,800 listed readings and/or textbooks, and 591 had no required or assigned items, although they may have listed optional and recommended materials for the students.

The distribution of syllabuses among institutions ran from a high of 386 syllabuses ( $11.4 \%$ of total collected) from Western University to the two $(0.1 \%)$ collected from Kwantlen Polytechnic University, with a mean of 99.7 syllabuses per university. Of the 3,391 syllabuses, $86.3 \%$ $(2,926)$ are in English, and $13.7 \%$ (465) are in French. Using an algorithmic assignment of syllabuses to basic academic divisions, manually checked by student coders, we determined that science courses account for $42.6 \%(1,443)$ of the syllabuses, the social sciences $37.1 \%(1,258)$, and the humanities $20.3 \%$ (690). No distinction is made between graduate and undergraduate course syllabuses as the Access Copyright tariff applies to all university students. While we were unable to locate a reliable source of information on how many courses are taught in Canada annually, if the country's roughly 1.3 million full-time university students may be assumed to be taking 8.2 courses a year in classes averaging 25 students, then this sample of 3,391 syllabuses would amount to a little less than $0.9 \%$ of the courses offered annually from $2015-2020 .^{5}$

\section{Categorizing the Readings}

This study involved a manual counting of the assigned or required course readings on the syllabuses (leaving aside optional or supplementary readings). We recruited and trained a group of 17 undergraduate students, a number of whom were competent in French, to categorize the assigned readings on the syllabuses (as distinct from textbooks and assigned whole books) into four types of readings (see students' training materials):

\section{Academic publications}

(a) Journal articles, which were identified by the name of the publication and the inclusion of volume and number in the syllabus's bibliography.

(b) Academic book chapters, which were identified by the academic nature of the book title, a list of leading academic publishers, and any university press.

Trade publications

(a) Media articles, which were identified by the non-academic publication's title, if not al- 
Table 1

Syllabus Sample by Assigned Items and Subject Area $(N=3,391)$

\begin{tabular}{ll}
\hline Documents & Count (\%) \\
\hline Web-scraped documents & 5,898 \\
Unique syllabuses & 3,916 \\
Minus syllabuses with readings elsewhere & 525 \\
Sample of analyzable syllabuses & $3,391(100)$ \\
Syllabuses with assigned items & $2,800(82.6)$ \\
Syllabuses with no required items ${ }^{\mathrm{a}}$ & $591(17.4)$ \\
Total & $\underline{3,391(100)}$ \\
Science syllabuses & $1,443(42.6)$ \\
Social Sciences syllabuses & $1,258(37.1)$ \\
Humanities syllabuses & $690(20.3)$ \\
Total & $\underline{3,391(100)}$ \\
\hline
\end{tabular}

Note

${ }^{a}$ Examples of syllabus statements referring to there being no required items: "Optional textbook authored by the instructor"; "aucun manuel n'est obligatoire"; "no required text for the course"; "livres de référence"; "following texts are not mandatory but may serve as useful reading material."

ready known media outlet, with a screen-full used as a unit for the "page count."

(b) Trade book chapters and book excerpts, which were identified by the non-academic nature of the title and publisher, in contrast to the academic publishers.

In addition, students were asked to identify textbooks, for which training was also provided. Textbooks that were assigned to students, as well as complete academic and trade books generally (with at least five chapters assigned, if not the whole book), are not considered assigned readings for the purposes of this study. This is because on purchasing them, students compensate the authors and publishers directly rather than through an Access Copyright tariff, as is the case with copies of readings.

The students trained to categorize the readings had to score $80 \%$ or better on a test set of syllabuses that the lead researcher had scored by reading type. Once underway, students were asked to cross-check a small sample (5-20) of each other's scored syllabuses, with discrep- ancies resolved by a third student (who had demonstrated relatively consistent scores in cross-checking), with the lead researcher stepping in as needed. When other scoring discrepancies were discovered, a few of the more proficient students were entrusted with re-analysis. In addition, the students recorded page counts on a sample of readings that provided page number information (Table 2). The page counts were totalled and divided by the number of readings sampled to come up with an average pages-per-reading for each reading type.

\section{Syllabus Analysis}

\section{Assigned Readings}

A little more than a quarter of the syllabuses, at $27.2 \%$ (923), assigned readings to the students as part of their coursework (Table 3). Of these syllabuses, $97.7 \%$ (902) assign readings from academic publications. In addition, among the four different types of readings used in 


\section{Table 2}

Reading Types by Average Number of Pages Per Reading, Based on Readings that Provided Page Ranges

\begin{tabular}{lll}
\hline Reading type & Paged readings (\%) ${ }^{\mathrm{a}}$ & Pages / reading \\
\hline Academic Readings & & 18.3 \\
Journal articles & $831(10.4)$ & 21.7 \\
Scholarly book chapters & $414(8.4)$ & \\
Non-Academic Readings & & 10.6 \\
Media articles & $226(25.9)$ & 20.0 \\
Trade book chapters & $390(42.5)$ & \\
\hline $\begin{array}{l}\text { Note } \\
\text { a Percentages for "paged readings" represent the proportion thereof relative to the total amount of assigned readings of that type in the full } \\
\text { syllabus sample. }\end{array}$
\end{tabular}

this analysis, the journal articles form the largest group. There were 7,961 journal articles assigned on 707 syllabuses (20.8\% of all syllabuses), with a certain clustering effect that amounted to an average of 11.3 journal articles assigned on those syllabuses with any of this type. In a fifth of the courses, then, instructors were asking students to engage with primary sources for current research, which is a commendable pedagogical strategy. Scholarly book chapters $(4,906)$ appeared on just about as many syllabuses, at $702(20.7 \%)$, as journal articles, though in smaller clusters, with 7.0 scholarly book chapters on average appearing on the syllabuses with such chapters.

Non-academic readings were considerably less prevalent among the syllabuses. On 194 syllabuses ( $5.7 \%$ of all syllabuses) were found 873 media articles in clusters of 4.5 items on average. And on 148 (4.4\%) syllabuses, 918 trade book chapters were distributed in clusters of 6.2 chapters per syllabus. The considerable mixing of reading types on the syllabuses is indicated by comparing the number of syllabuses with readings (923) to the totals for each type of reading, as well as the grand total of 14,658 readings.

In terms of the distribution of reading types across the three academic areas, syllabuses in the social sciences assigned 5,264 journal articles on 457 syllabuses (36.3\%), followed by the humanities, with 1,656 journal articles assigned on 165 syllabuses (23.9\%), and science, with 1,041 such readings assigned on 85 syllabus- es (5.9\%) (Table 4). The social sciences also assigned a greater number of scholarly book chapters, as well as media articles, compared to the other two areas, in relative and absolute terms. On the other hand, the humanities syllabuses led in trade-book chapters, with 570 on 64 syllabuses $(9.3 \%)$.

\section{Textbooks}

Although textbooks are not the focus of this analysis, it is still worth noting that roughly two-thirds of syllabuses in the sample $(2,238 ; 66.0 \%)$ had an assigned textbook (Table 5). This is more than twice as many syllabuses that had assigned readings (923 syllabuses: $27.2 \%$ ) (Table 3). The textbooks were assigned in relatively similar proportions across the three subject areas, with $69.3 \%$ of the science syllabuses requiring a textbook, $60.0 \%$ of the social sciences syllabuses, and $70.0 \%$ of the humanities syllabuses. Given the frequency with which courses rely on textbooks, it is worth noting that the steady price increases for textbooks over the last few decades have begun to level off, under pressure, perhaps, from open textbook initiatives (e.g., OpenStax, BC Open Textbooks), which represent another aspect of the digital transformations specific to academic publishing (Fox, 2020; Jhangiani, 2018). There is some overlap, with 361 syllabuses ( $10.6 \%$ of the total) listing a required textbook and at least one assigned reading. 


\section{Table 3}

Assigned Academic and Non-academic Reading Types on Canadian Syllabuses ( $N=3,391)$, with Average Clustering of Types Per Syllabus with the Reading Type

\begin{tabular}{llll}
\hline Reading type & Assigned (\%) & Syllabuses (\% total) & Cluster / syllabus \\
\hline a) Academic readings & $12,867(87.8)$ & $902(26.6)$ & 14.3 \\
i) Journal articles & $7,961(54.3)$ & $707(20.8)$ & 11.3 \\
ii) Scholarly book chapters & $4,906(33.5)$ & $702(20.7)$ & 7.0 \\
b) Non-academic readings & $1,791(12.2)$ & $281(8.3)$ & 6.4 \\
i) Media articles & $873(6.0)$ & $194(5.7)$ & 4.5 \\
ii) Trade-book chapters & $918(6.3)$ & $148(4.4)$ & 6.2 \\
All readings & $14,658(100)$ & $923(27.2)$ & 15.9 \\
\hline
\end{tabular}

Note

${ }^{a}$ Syllabuses do not add up to $100 \%$ because of overlap of reading types on syllabuses.

\section{Table 4}

The Distribution of Reading Types by Academic Area, Readings, Syllabuses of Which They Are Found, and Pages Per Area Syllabuses $(N=3,391)$

\begin{tabular}{llll}
\hline Area & Reading type & Readings & Syllabuses (area \%) \\
\hline Science & Journal articles & 1,041 & $85(5.9)$ \\
$\mathrm{n}=1,443$ syllabuses & Scholarly book chapters & 329 & $72(5.0)$ \\
& Media articles & 46 & $16(1.1)$ \\
& Trade book chapters & 15 & $5(0.3)$ \\
& Total & $\underline{1,431}$ & $\underline{113(7.8)}$ \\
Social Sciences & Journal articles & 5,264 & $457(36.3)$ \\
$\mathrm{n}=1,258$ syllabuses & Scholarly book chapters & 3,150 & $427(33.9)$ \\
& Media articles & 675 & $142(11.3)$ \\
& Trade book chapters & 333 & $79(6.3)$ \\
Humanities & Total & $\underline{9,422}$ & $\underline{551(44.0)}$ \\
$\mathrm{n}=690$ syllabuses & Journal articles & 1,656 & $165(23.9)$ \\
& Scholarly book chapters & 1,427 & $203(29.4)$ \\
& Media articles & 152 & $36(5.2)$
\end{tabular}




\begin{tabular}{llll}
\hline Area & Reading type & Readings & Syllabuses (area \%) \\
\hline & Trade book chapters & 570 & 64 (9.3) \\
& Total & $\underline{3,805}$ & $\underline{257}(37.2)$ \\
\hline
\end{tabular}

Note

${ }^{\text {a }}$ Syllabuses in each of the three areas do not add up to $100 \%$ because of reading type overlap on syllabuses within the area.

\section{Table 5}

The Assignment of Textbooks in Canadian University Syllabuses $(N=3,391)$

\begin{tabular}{lll}
\hline Syllabuses & Assigned textbooks & Syllabuses w/ textbooks (\%) \\
\hline All syllabuses & 3,198 & $2,238(66.0)$ \\
Science syllabuses & 1,240 & $1,000(69.3)$ \\
Social Science syllabuses & 1,016 & $755(60.0)$ \\
Humanities syllabuses & 942 & $483(70.0)$ \\
\hline Note & & \\
${ }^{a}$ Percentages for "syllabuses w/ textbooks" are for all syllabuses and for the syllabuses in an area.
\end{tabular}

\section{Calculating Costs}

At this point, we use the data from the syllabuses to arrive at a rough estimate of the royalty charges currently levied on course readings which we plan to use below to calculate what we argue is a more appropriate basis for arriving at an annual tariff. This began by calculating that the syllabuses assigned an average of 82.6 pages (Table 6). With Statistics Canada offering that students take an average of 8.2 courses a year, this amounts to 677.3 pages of readings annually. If one then takes the Copyright Board of Canada-approved annual tariff of $\$ 14.31$ per student, this works out to a payment of $\$ 0.021$ per page for all types of assigned readings. ${ }^{6}$ This rate can be neatly divided up at \$0.007 per page for (a) authors, (b) publishers, and (c) Access Copyright. As it turns out, $\$ 0.007$ per page corresponds to what authors receive for a typical paperback sale in a bookstore. ${ }^{7}$ It also roughly matches Access Copyright's 35\% charge for "administrative holdback" (Access Copyright, 2021a). It somewhat undercuts the publishers' more typical 60/40 split with authors under Access Copyright, although none of these calculations is above criticism (Geist, 2008). We apply this combined rate of $\$ 0.021$ per page in our proposed three-step syllabus rule below.

\section{Discussion}

In determining a fair price to charge for the use of published materials assigned in Canadian university courses, a number of considerations need to be taken into account. From our perspective, the first of these is that the journal articles and scholarly book chapters-which account for $90.1 \%$ of the pages assigned to students (Table 6) - form a distinctive scholarly publishing economy that has operated at a remove from that of trade publishing for centuries. We believe that distinctions between scholarly and trade publishing warrant an alternative approach to the handling of university course readings that we wish to illustrate using the data assembled here. This bears on the 2020 Federal Court of Appeal ruling on York v. Access Copyright, which noted that "York did not justify [its claim to 'fair dealing'] beyond invoking education as an allowable purpose" (York University v. Canadian Copyright Licensing Agency, 2020, para. 258). ${ }^{8}$ In response to the ruling's point on justification, the three-step syllabus rule proposed here offers a more thorough limiting and tailoring of the claims of fair dealing for university course readings based on the distinctions between the scholarly and trade publishing economies. ${ }^{9}$ We recognize that this 


\section{Table 6}

Reading Type by Syllabus and Pages Per Item and Per Syllabus ( $N=3,931)$

\begin{tabular}{llll}
\hline Reading type & Reading / syllabus & Pages / item & Pages / syllabus (\%) \\
\hline Academic Readings & & & \\
Journal articles & 2.3 & 18.3 & $43.0(52.1)$ \\
Scholarly book chapters & 1.4 & 21.7 & $31.5(38.1)$ \\
Non-academic readings & & & \\
Media articles & 0.3 & 10.6 & $2.7(3.3)$ \\
Trade book chapters & 0.3 & 20.0 & $5.4(6.6)$ \\
All readings & & 19.1 & $82.6(100)$ \\
\hline
\end{tabular}

Note

a Weighted average used for "pages per item" for "all readings."

will call for an agreement on the assignment of reading types, based in part on distinguishing between academic and professional authorship. The technical aspects of the three proposed steps are described in the appendix, with a summary here.

\section{Check Library Holdings and Open Access}

A university's syllabuses would be analyzed by an artificial intelligence system, such as Open Syllabus, to determine which assigned readings are covered by its institutional licences and by open access. ${ }^{10}$ The materials the university does not yet license would be treated as acquisition recommendations, given their value to instructors, which leads to the second step. The non-academic readings for which the university does not hold an institutional licence would go to the third step for processing. ${ }^{11}$

\section{Limit Fair Dealing}

The second step applies to the scholarly readings that are not (yet) available to students through Step 1. For these materials, an innovative and limited appeal is made to the fair dealing exception of the Copyright Act. What qualifies these scholarly readings as fair dealing is that any "substantial adverse effect, financial or oth- erwise, on the exploitation...of the existing work" (which might impede fair dealing) experienced by publishers will be neutralized by the authors' reputational benefits of having their work assigned in university classes (Copyright Act, 1985, sec 29.21, 1d). ${ }^{12}$ This desirable exploitation of authors' work leads to financial gains in career development, as well as further sales for the publishers of the authors' works. ${ }^{13}$ Even if, as is likely, authors have given up their copyright in the assigned work, the Copyright Act still recognizes their moral rights, which relate to the protection of their "honour or reputation" (Copyright Act, 1985, sec 28.2, 1). ${ }^{14}$ This appeal to fair dealing, which only applies to the academic readings not covered in the first step of this approach, is further strengthened by the final step.

\section{Deal Fairly with Professional Writers}

The third step applies to media articles and trade book chapters, including essays, short stories, and poetry, that are not licensed by the institution. This work warrants payment because professional writers depend on royalties rather than university employment. Furthermore, university faculty assign their works to achieve their own, their students', and their institution's instructional goals. If academic authors benefit financially from the reputational gain, then professional authors are no less deserving of reward, rather than being subject to 


\section{Table 7}

Average Non-academic Reading Costs for all Syllabuses at $\$ 0.021 /$ page $(N=3,391)$

\begin{tabular}{llll}
\hline Reading type & Reading / syllabus & Pages / item & Cost / syllabus \\
\hline Media articles & 0.3 & 10.6 & $\$ 0.057$ \\
Trade book chapters & $\underline{0.3}$ & $\underline{20.0}$ & $\$ 0.114$ \\
Total non-academic readings & 0.5 & 15.4 & $\$ 0.171$ \\
\hline Note & & \\
a The total "non-academic readings" per syllabus include an overlap of media articles and trade book chapters, while the "pages/item" for \\
"non-academic readings" is an average of the two types.
\end{tabular}

a fair-dealing blanket exception for this million-student market in Canada, with more on the financial and existential "substantial adverse effect" to follow (Copyright Act, 1985, sec 29.21, 1d).

Following this three-step approach to paying royalties, we recommend that the Copyright Board's approved tariff of $\$ 14.31$ per student be applied on a prorated basis to cover only the media articles and trade book chapters (as per Step 3 above). The professional writings assigned to students amounts to 0.5 readings per syllabus and 15.4 pages per reading on average (Table 7). At the current tariff rate of $\$ 0.021$ per page, this works out to $\$ 0.171$ a syllabus for students' use of professional writings in media pieces and trade book chapters. With students carrying an average load of 8.2 courses a year, this $\$ 0.171$ per syllabus amounts to an annual charge of $\$ 1.40$ per student, based on our sample of 3,391 syllabuses from 2015 to 2020.

This application of the three-step syllabus rule will avoid double-charging students for works to which they already have licensed access. It will provide the professional writers with a return on their writings in university classes that is roughly comparable to the rate that they earn from bookstore sales. In total, authors, publishers, and Access Copyright would collect, under the three-step syllabus rule, $\$ 1,769,888$ a year from Canada's roughly 1.2 million full-time university students (or their institutions) for the readings assigned in courses. ${ }^{15}$ Although the amount may seem de minimis (in a legal sense not worth pursuing), we side with the "many poets" in Eli MacLaren's study of Canadian poets' income (which found royalty payments amounted to $2 \%$ of their income), who nonetheless "described the validation that even a little money brings with it" (2017, p. 20). The application of the threestep syllabus rule provides for the validation of poets, as well as the recognition of academics. ${ }^{16}$ While there is room for this annual fee of $\$ 1.40$ per student to grow over time, it stands in contrast to the $\$ 26.00$ per student that Access Copyright is currently requesting from the Canadian Copyright Board (Copyright Board of Canada, 2019).

\section{Conclusion}

This analysis of Canadian university syllabuses reveals that the largest proportion of assigned readings is drawn from academic sources. This calls for a recognition of both the sponsored economy of higher education that leads to the production of these writings, and the extent to which students are double-charged for these readings. While the analysis of Canadian syllabuses does not, by any means, dictate the policy terms of a fair and reasonable strategy for compensating the producers of the materials used in these courses, the analysis does provide a means of assessing the outcomes of a proposed policy, which is what we have done here with the three-step syllabus rule. The rule would eliminate the double-charging, and it would redirect the differences in economies between scholarly and trade publishing toward a recognition of the contribution made by writers from outside the academy to higher education in a way that is fair for students, authors, and publishers.

\section{Acknowledgements}

The authors wish to express their appreciation to the following students whose assistance made this study 
possible in the old school manner of discerning manual analysis: Burcu Alici, May Aye, Sabina Blankenberg, Jane Boettcher, Grace Davis, Alexander Finan, Rio Flores, Samuel Good, Clem Harrington, Habeeb Jimoh, Via Lamberti, Allan Lopez, Ben Nguyen, Valexa Orelien, Doris Rodriguez, Nicole Salazar, and Ava Snow. We are also grateful to Joe Karaganis, director of the Open Syllabus Project, who has consulted with us on how this technology could be used to implement the proposed three-step syllabus rule, as well as Ariel Katz for detailed counsel on Canadian legal matters, and the two perceptive reviewers for this journal.

\section{Conflict of Interest}

John Willinsky has received royalty payments from Access Copyright over the last two decades. Catherin Baron has no conflicts.

\section{References}

Access Copyright. (2021a). Publisher distribution guidelines. https://www.accesscopyright.ca/publishers/distribution-guidelines/

Access Copyright. (2021b). Educators FAQ. https:// www.accesscopyright.ca/educators/access-forcopyshops-faqs/

Bohannon, J. (2016). Who's downloading pirated papers? Everyone. Science. https://www.sciencemag. org/news/2016/04/whos-downloading-pirated-papers-everyone

Burgess, M., \& De Rosa, M. (2017). The remuneration of Canadian writers for literary works: A benchmarking study. MDR Communications. https://www.writersunion.ca/sites/all/files/attachments/Study\%20 on\%20Remuneration $\% 20$ of $\% 20$ Writers $\% 20$ September\%202017 0.pdf

Canadian Association of University Teachers. (2013). Joint objection of the Canadian Federation of Students and the Canadian Association of University Teachers to the Access Copyright post-secondary educational institution tariff, 2014-2016. https:/l www.caut.ca/docs/default-source/copyright/cautcfs-objection-to-access-copyright-tariff-(2014-2016). pdf?sfvrsn=4
Canadian Copyright Licensing Agency v. York University, 2017 FC 669 (CanLII), [2018] 2 FCR 43. https://www.canlii.org/en/ca/fct/doc/2017/2017fc669/2017fc669.html

Cancilla, N., Glushko, B., Orfano, S., \& Slaght, G. (2017). Engaging faculty and reducing costs by leveraging collections: A pilot project to reduce course pack use. Journal of Librarianship and Scholarly Communication, 4, 1-22. https://ir.lib. uwo.ca/wlpub/56/

Canuel, R., \& Crichton, C. (2011). Canadian academic libraries and the mobile web. New Library World, 112(3/4), 107-120. https://doi. org/10.1108/03074801111117014

Carbaugh, B. (2020). The decline of college textbook publishing: Cengage Learning and McGraw-Hill. American Economist, 65(2), 284-299.

CCH Canadian Ltd. v. Law Society of Upper Canada, 2004 SCC 13 (CanLII), [2004] 1 SCR 339. https:/l decisions.scc-csc.ca/scc-csc/scc-csc/en/item/2125/ index.do

Chapdelaine, P. (2021). Fair dealing for the purpose of education: York University v The Canadian Copyright Licensing Agency. Preprint, SSRN. https://papers. ssrn.com/sol3/papers.cfm?abstract id=3808146

Copyright Act, RSC 1985, c. C-42. https://laws-lois. justice.gc.ca/eng/acts/C-42/Index.html

Copyright Board of Canada. (2019). Access Copyright - tariffs for post-secondary educational institutions, 2011-2017. https://decisia.lexum.com/ cb-cda/r/en/item/453964/index.do?q=access+copyright+\%28post-secondary+educational+institutions

Evans, B. J., \& Willinsky, J. (2013). Setting aside the course reader: The legal, economic, and pedagogical reasons. Innovative Higher Education, 38(5), 341-354.

Fox, J. (2020, February 8). College students catch a break on one cost at least. Bloomberg. https://www. bloomberg.com/opinion/articles/2020-02-08/college-textbook-prices-plateau-with-rentals-and-digital-options

Frey, M. G. (1998). Unfairly applying the fair use 
doctrine: Princeton University Press v. Michigan Document Services. University of Cincinnati Law Review, 66(3), 959-1018.

Geist, M. (2008, February 15). Independent report blasts access copyright over lack of transparency. Michael Geist. https://www.michaelgeist. ca/2008/02/access-copyright-report/

Geist, M. (2014a, December 10). Too little, too late?: Access copyright finally acknowledges the reduced value of its license. Michael Geist. https://www.michaelgeist.ca/2014/12/little-late-access-copyright-finally-acknowledges-reduced-value-licence/

Geist, M. (2014b, February 7). Who gets a large share of Access Copyright education licensing revenues? US publishers say they do. Michael Geist. https:/l www.michaelgeist.ca/2014/02/ac-licensing-share/

Jhangiani, R. (2018, January 2). To combat soaring textbook costs, look to an open-source approach. Globe and Mail. https://www.theglobeandmail.com/ opinion/to-combat-soaring-textbook-costs-look-toan-open-source-approach/article37477566/

Karaganis, J., \& McClure, D. (2016, January 22). What a million syllabuses can teach us. New York Times. https://www.nytimes.com/2016/01/24/opinion/sunday/what-a-million-syllabuses-can-teach-us.html

Katz, A. (2021). Factum of the interveners, Authors Alliance and Ariel Katz. Authors Alliance. https://www.authorsalliance.org/wp-content/uploads/2021/04/39222 Factum Interveners AuthsAll FINAL.pdf

Limitations. (2020). Section 107. Limitations on exclusive rights: Fair use. Copyright Act of 1976 . Washington. https://www.copyright.gov/title17/92chap1.htm|\#107

MacLaren, E. (2017). Copyright and poetry in twenty-first-century Canada: Poets' incomes and fair dealing. Canadian Literature, 233(Summer): 10-27. https://canlit.ca/full-issue/?issue=233

Parnell, S., Hobart, M., \& Wilson, B. (2003). Managing digitisation of course readers through internal and external partnerships [Doctoral dissertation, University of South Australia], http://citeseerx.ist.psu.edu/viewdoc/download?$\underline{\text { doi=10.1.1.133.5287\&rep=rep1\&type=pdf }}$
Pflugfelder, E. H. (2012). Translucency, coursepacks, and the post-historical university: An investigation into pedagogical things. College English, 74(3), 247-267.

Piwowar, H., Priem, J., Larivière, V., Alperin, J. P., Matthias, L., Norlander, B., Farley, A., West, J., \& Haustein, S. (2018). The state of OA: A large-scale analysis of the prevalence and impact of Open Access articles. PeerJ, 13(6), e4375. https://doi. org/10.7717/peerj.4375

Piwowar, H. Priem, J., \& Orr, T. (2019). The future of OA: A large-scale analysis projecting Open Access publication and readership. bioRxiv, 795310(2019). https://www.biorxiv.org/content/10.1101/795310v1

Public Lending Right. (2020). Annual report, 20192020. Canada Council of the Arts. https://publiclendingright.ca/-/media/Files/Plr/AnnualReports/ AnnualReport2019-2020.pdf

Rojeski, M. (2012). User perceptions of ebooks versus print books for class reserves in an academic library. Reference Services Review, 40(2), 228-241.

Ruimy, D. (2019). Statutory review of the Copyright Act: Report of the Standing Committee on Industry, Science and Technology. https://www.ourcommons.ca/Content/Committee/421/INDU/Reports/ RP10537003/indurp16/indurp16-e.pdf

Schow, E. (2020, October 6). GSU prevails in long-running fair use fight. Brigham Young University Copyright Licensing Office Blog. https://copyright.byu. edu/the-georgia-state-case-reaches-a-milestone

Seligman, R. A. (2020). Finding the right textbook. In R. A. Seligman (Ed.), How to teach a course in research methods for psychology students (pp. 21-26). Springer.

Shepherd, I. D., \& Bleasdale, S. (1993). Student reading and course readers in geography. Journal of Geography in Higher Education, 17(2), 103-121

Statistics Canada. (2018). Postsecondary enrolments, by field of study, registration status, program type, credential type and gender (Table: 37-10-0011-01). https://www150.statcan.gc.ca/t1/tbl1/en/cv.action?pid=3710001101

Statistics Canada. (2019). Student pathways through 
postsecondary education in Canada, 2010 to 2015. The Daily. https://www150.statcan.gc.ca/n1/daily-quotidien/191018/dq191018a-eng.htm

Statistics Canada. (2020). Postsecondary student information system (PSIS). https://www.statcan.gc.cal en/survey/business/5017

Tabacaru, S., \& Hartnett, E. (2017). How academic libraries provide value through course readings. Journal of Electronic Resources Librarianship, 29(1), 24-36.

York University v. Canadian Copyright Licensing Agency, 2020 FCA 77 (CanLII). FCA 77. https://www. canlii.org/en/ca/fca/doc/2020/2020fca77/2020fca77. html?autocompleteStr=2020\%20FCA\%2077\&autocompletePos $=1$

Wilkinson, S. (2019). Justifying the unjustifiable: Canadian Copyright Licensing Agency ("Access Copyright") v. York University. Intellectual Property Journal, 31(2), 187-216.

Willinsky, J. (2017). The intellectual properties of learning: A prehistory from Saint Jerome to John Locke. University of Chicago Press.

Willinsky, J. (2019, November 20). The Open Access Consensus and Copyright Reform. Slaw.ca. https:// www.slaw.ca/2019/11/20/the-open-access-consensus-and-copyright-reform/

Willinsky, J. (2020, November 10). A new three-step syllabus rule for dealing fairly with university course readings. Slaw.ca. http://www.slaw.ca/2020/11/10/anew-three-step-syllabus-rule-for-dealing-fairly-withuniversity-course-readings

World Intellectual Property Organization. (1979). Berne Convention for the Protection of Literary and Artistic Works (as amended on September 28, 1979). https://wipolex.wipo.int/en/text/283698

\section{Contact Information}

John Willinsky

willinsk@stanford.edu

The data and its analysis for this study is available here.

\section{Notes}

1 Scholarly publishing is also distinguished by (a) the absence of royalties paid to journal authors; (b) the (unpaid) peer reviewing process; (c) the use of part-time professorial journal editors; (d) the tax-exemptions for massive publishing enterprises such as Oxford University Press; (e) the extremely high profits earned by the commercial sector; and (f) a recent scholarly-publishing-stakeholder consensus that open access to research is best for science, with close to a third of the research journal literature made freely available to readers by 2017 , not counting the Sci-Hub massive illegal cache (Piwowar et al., 2018; Bohannon, 2018).

2 The four factors considered for fair use limit on copyright: "(1) Purpose and character of the use [of the work]... (2) nature of the copyrighted work; (3) amount and substantiality... (4) effect of the use upon the potential market" (Limitations, 2020).

3 In 2012, Canada amended the Copyright Act so that copying for the purpose of "education" (as well as research, private study, parody or satire, as well as criticism, review, and news) is "fair dealing" and, as such, "does not infringe copyright" (Copyright Act, 1985). With what including education means still not well defined by the courts, a quarter of Canada's 96 universities have refused to pay the Access Copyright tariff (Access Copyright, 2021a). Michael Geist: "For many years, the universities effectively funded Access Copyright's litigation and Copyright Board costs, with the collective setting aside millions to pay for legal and lobbying fees" (2014a).

4 York's guidelines advise that "a single copy of a short excerpt from a copyright-protected work may be provided or communicated to each student enrolled in a class or course" ("Fair Dealing," 2012).

5 An average load of 8.2 courses is based on the StatsCan calculation of the "average time to obtain an undergraduate degree," which is 4.49 years or 8.9 courses/year (Statistics Canada, 2019). With no comparable figure for graduate students, their load was treated as half that of undergrads and, using the ratio of undergraduate to graduate students, the average was 8.2 courses for Canadian university students in 2018/2019 (Statistics Canada, 2020).

6 The Copyright Board's rate is based, Ariel Katz has cautioned us, on very few data points (personal correspondence, April 25, 2021). It works out to $\$ 0.021 /$ page, compared to Access Copyright's posted rate of $\$ 0.15$ per page for course materials (Access Copyright, 2021b). Also note that in this article, we use one-tenth of a cent for making calculations (e.g., \$0.021/page) up to the point of our proposed tariff rate for students, for which 
standard financial notation is used (e.g., \$1.40).

7 The $\$ 0.007$ author page rate was arrived at by assembling the list prices and page counts for 10 current trade and mass paperbacks (fiction and non-fiction) in Canada, and applying the typical $10 \%$ royalty rate with this data included in the data set deposited with this article (Burgess \& De Rosa, 2017).

8 "Fair dealing" in the Copyright Act is an "exception to infringement" that is granted to a user who copies a work for purposes of "education" among others purposes, and when that copying is (a) not commercial, (b) the source is given, (c) the work itself does not infringe, and (d) "the use...does not have a substantial adverse effect, financial or otherwise, on the exploitation... of the work" (Copyright Act, 1985, sec 29.211).

9 This rule is a syllabus-specific variation on the three-step test in the Berne Convention for the Protection of Literary and Artistic Works, which is defined as the following: "It shall be a matter for legislation in the countries of the Union to permit the reproduction of such works in certain special cases, provided that such reproduction does not conflict with a normal exploitation of the work and does not unreasonably prejudice the legitimate interests of the author" (World Intellectual Property Organization, 1979, Article 9.2). The syllabus rule was first introduced by Willinsky in a SLAW.ca column (2020).

10 Open Syllabus is a non-profit research organization that has collected 355,032 syllabuses from Canadian colleges and universities for the years 2013 to 2017, from which it can extract and analyze the readings listed (Karaganis \& McClure, 2016).

11 In the original court decision against York University, Justice Phelan argued: "York has argued that because it has separate licenses and permissions, the amount of copying at issue is reduced. However, York has conceded that its evidence on licensing information is inaccurate and its ability to marry up with the relevant license information is impossible to rely on" (Canadian Copyright Licensing Agency, 2017, para. 287).

12 This is in accord with the Supreme Court of Canada ruling that "the fair dealing exception...must not be interpreted restrictively" and further that "it may be relevant to consider the custom or practice in a particular trade or industry to determine whether or not the character of the dealing is fair" (CCH Canadian Ltd. v. Law Society of Upper Canada, 2004, paras 48, 55).

13 In 2013, the Canadian Association of University Teachers set aside concerns with royalties to join with the Canadian Federation of Students in objecting to the Access Copyright Post-Secondary Educational Institution Tariff, 2014-2016 (Canadian Association of University Teachers, 2013).
14 "An assignment of copyright in a work does not by that act alone constitute a waiver of any moral rights" (Copyright Act, sec 14.1(3)).

15 This amount can be compared, for example, to $\$ 14.7 \mathrm{mil}-$ lion distributed through the Public Lending Right to close to 20,000 Canadian authors in 2019-2020. (Public Lending Right, 2020).

16 While MacLaren rightly holds that state sponsorship, such as the Canada Council, is key to "the economics of poetry," the validation signalling offered by the three-step syllabus rule's royalty payments to professional writers and their publishers should not undermine that poetic economy (2017, p. 10). Nor should as large a share of the rule's royalty payments end up going to the United States, as has been the case in other Access Copyright agreements (Geist, 2014b). This is because the proportion of Canadian professional writers, including poets, can be expected to be much higher than when the research literature is included in the agreement, very little of which is published in Canada. 


\section{Appendix}

\section{How the Open Syllabus Project Makes the Proposed Three-Step Syllabus Rule Feasible}

To determine the royalty costs for readings assigned in university courses under what we are proposing as a "three-step syllabus rule" (3SSR), the institution would establish an account with Open Syllabus (OS) and submit to OS the coming semester's syllabuses. OS uses artificial intelligence and external databases to identify the works assigned to students on the institution's course syllabuses, including textbooks, monographs, and scholarly articles, as well as non-traditional teaching materials such as newspaper and magazine pieces, blogs, television programs, and YouTube videos. By following the three steps set out below, OS provides an automated and increasingly accurate approach to avoiding double-charging students for items already licensed, as well as for open access items, while providing faculty and administrators with legal assurances in their use of materials, as well as a list of hyperlinks to appropriate copies.

\section{Step 1}

(a) Instructors would make their syllabuses available to their institution's OS account through a URL, PDF, Word, or Google document, or a course management system.

(b) OS would sort through assigned readings in syllabuses and...

(i) Send academic publications (journal articles or scholarly publishers' book chapters) to Step 1(c);

(ii) Send media items and trade book chapters to Step 3;

(iii) Send problematic syllabus items back to instructors for clarification (which would be used to update OS).

(c) For academic publications, OS would...

(i) Check library's catalogue for a digital edition with an institutional licence;

(ii) Check for an open access version through Unpaywall, DOAJ, DOAB, etc.

(d) OS would then...

(i) Produce for instructors a list of links for items found in Step 1(c);

(ii) Send to Step 2 those academic items that are not (yet) found in Step 1(b).

\section{Step 2}

(a) OS turns the academic items not found in Step 1(c) into a list of purchase recommendations for the library (with frequency of appearance and repeated use).

(b) These items can be used under "fair dealing" in Canada (or "fair use" in the United States; see preprint); the list can be monitored to establish that the library is acting in good faith.

Step 3

(a) OS calculates royalty payments for media items and trade book chapters based on approved rates.

(b) OS generates and submits invoices on behalf of collective management organization whether at the level of (i) institution, (ii) division, or (iii) syllabus. 